\title{
My Marriage Journey: \\ Could Misinterpretation of Religious Script Lead to Misguided Spirituality?
}

\author{
Sindile A. Ngubane-Mokiwa \\ ORCID iD: https://orcid.org/0000-0003-0998-7828
}

\begin{abstract}
When I embraced Islam 24 years ago, I was excited about the aspects of the Qur'an (Holy Scripture) that liberated women. As an African woman, I am familiar with cultural traditional and religious practices that subject women to oppression and dehumanisation. Within this framework, I joined Islam, because of the liberating potential that the Qur'an offers women. Utilising autoethnography as my methodology and critical feminism as my lens, this paper outlines the basic tenets of Islam that guide and influence my behaviour and how it correlates with my marital life. Furthermore, I explore the extent to which (mis)- or (re)interpretation of religious texts may lead to misguided spirituality. My conclusions illustrate that Islamic pedagogies, in its ideological space, promote women's human rights, but due to the socio-political structures and cultural conditioning that perpetuate obedience and subjection of women and children, it is interpreted to reinforce power relations.
\end{abstract}

Keywords: autoethnography, coping mechanisms, emotional abuse, financial abuse, gender-based violence, spirituality

\section{Introduction}

In Islam, marriage is a sacred and social contract between two parties. Qur'an 4:1 states: 'O men! Fear your Lord Who created you from a single being and out of it created its mate'. Sacredness implies that failure to comply to abstinence before marriage angers Allah. To avoid punishment, Muslims are discouraged from dating before marriage, or encouraged to have a mahram (chaperon) accompany them when unrelated men and women interact. 
Muslims are encouraged to marry as soon as they have fulfilled the following: they are both adults and sane; have agreed to stay together as husband and wife, and a dowry (marriage gift) has been given to the bride. The marriage gift can be paid in full immediately (muajjal), or at a later stage (muakhkhar). The verse quoted above denotes that husband and wife are supposed to be mates who live lives of kindness, love, devotion and mutual respect.

Like any other girl from a village, I wanted to get married, so that I could fulfil half of my Islamic belief (Hassouneh-Phillips 2001b) and gain my autonomy. I had witnessed the ill-treatment of my spinster aunts, who were constantly being told that they had no right to determine the affairs of their fathers' homes, because they were old enough to make rules in their own houses. This attitude is accurately articulated by Chimamanda Ngozi Adichie in her book, We should all be feminists, in which she explains that African societies consider women who are not married at a certain age as inadequate human beings. In a society where grandmothers and mothers married relatively young (15 to 18 years), being older than 20 and unmarried veers from the normative, and is frowned upon by elders in the family. As soon as I completed my undergraduate studies, I was ready for marriage and familial responsibilities, which would include managing my own home and having children, through which I would be considered a respectable member of my community. The idea that marriage makes a woman a 'respectable member' of society is present in both Islamic and other conservative, culturally bound societies.

Khalil (2016) argues that interpersonal communication is a critical element of Islam. He posits that interpersonal communication is a social characteristic that leads to the attainment of common goals. Islam emphasises that all humans are social beings who realise their value by living in harmony with others. An-Nu'man ibn Basheer narrates that Prophet Muhammad (PBUH or SAW) said, 'The parable of the believers in their affection, mercy, and compassion for each other is that of a body. When any limb aches, the whole body reacts with sleeplessness and fever' (Șahịị al-Bukhārī 5665).

Through marriage, communities with common purposes are created, and women play a critical role in nurturing these ummah (communities of believers). Though men are regarded as the 'heads' or leaders of families and society, their rules/instructions are enforced by women. So, women ensure that there is harmony in the home by being conflict resolvers. Unfortunately, my experience was that, in some Muslim homes, women are not given the space to play this role effectively due to woman-on-woman rivalry. Mothers-in-law 
do not give their daughters-in-law the opportunity to navigate their marriages and domestic lives without conflict in the extended family.

The Qur'an that states that men are 'qawaam' (meaning strong and responsible) and, therefore, responsible for women and children. This 'strength' has been (re)interpreted to mean that they have liberty over decisionmaking and cannot be questioned; yet Allah (God) gave it as a responsibility to protect and oversee, not as a method of control. Overwhelmingly, men regard the 'strength' they supposedly have as permission to dominate their wives and families. Alghafli, Hatch and Marks (2014) assert that the Qur'an gives both Muslim men and women rights and responsibilities over each other. So, it is expected that if men were to carry out their responsibilities for the pleasure of Allah, while respecting the women's rights as prescribed in the Qur'an, there would be no conflict in marriages.

\section{Critical Feminism}

In reflecting on my marital journey, I employ critical feminism, which, according to Scatlas (1992), should be an ongoing project that involves 'criticizing, analyzing ... in order to eradicate the misrepresentation, distortion, and oppression resulting from historically male perspectives, use, understanding and practice of religious scripts'. MacKinnon (1983; 1991) asserts that critical feminism is based on the assumptions that,

Gender oppression is endemic in our society .... Traditional claims of gender neutrality and objectivity must be contested ... social justice platforms and practices are the only way to eliminate gender discrimination ... the experiential knowledge of women or their 'unique voice' is valid ... women are differentially discriminated against depending on the interests of the dominant group ... history and historical contexts must be taken into consideration in order to challenge policies and practices and that affect women ... [and] critical feminist theory must be interdisciplinary in nature (Geisinger 2011:13).

The socio-politico normative approach of critical feminism scaffolds an argument on women's marginalisation in Islamic marriage within African communities. The argument is that religion is always assumed to uphold morality, yet, in the case of Islam, experience has shown that it enforces male 
dominance (Ghorbani, Watson, Geranmayepour \& Chen 2013; 2014). Ghorbani et al. (2014) posit that, in Islam, spirituality is based on full submission to Allah; Pargament (2013:257) asserts that spirituality is the 'search for the sacred'. Hassouneh-Phillips (2003) sees spirituality as a means through which some women become more vulnerable to abuse.

Mangena (2009) posits that critical feminism and feminist ethics provide lenses through which women's experiences with men and society can be critiqued. She calls for careful application of African principles, such as ubuntu, which, she argues, can promote subjugation of women if it is not practiced fairly (2009:28). In this paper, I argue that misrepresented and misinterpreted religious texts can lead to misguided spirituality.

As much as I am guided by the principles of ubuntu, an African philosophy that promotes an 'humane, respectful and polite attitude towards others' (Ramose 1998:231), I take caution from Mbiti (1970:318), who warns that ubuntu,

tends to whittle down the autonomy of the person; that it makes the being and life of the individual person totally dependent on the activities, values, projects, and practices, and the ends of the community; and, consequently, that it diminishes his/ her freedom and capability to choose or question or re-evaluate the shared values of the community.

It is, therefore, crucial that women learn to be critical of their religious and cultural practices, to avoid self-oppression.

\section{Methodological Considerations}

Much research and publications on Muslim communities tend to focus on gender roles and the treatment of women (Macdonald 2006). This reflexive paper is autoethnographic in nature, as it presents my self-reflection (auto) of my personal marital experiences while participating in and observing the world and Muslim marital culture (ethnos) and capturing the experiences through writing (graphy) (Wall 2006). As a female researcher, I begin investigating my marital world from a grounded position in my own subjective oppression (Weiler 1988). This autoethnographic study is underpinned by my African Muslim standpoint. 


\section{My Marriage Journey and Misguided Spirituality}

I have witnessed many successful, unhappy and failed marriages. I did not date first, but followed the Islamic way of settling, and I knew I was taking a risk. However, there are people who date their partners first, and who think they understand them and are compatible, and then it does not turn out to be true. As I prayed, asking Allah for guidance in choosing a life partner, I reached the stage when I felt that marriage was not for me to control, but a sacred institution, purely in the Creator's capable hands. Siddiqi (1984) posits that 'the teachings of Islam, all duties, whether they concern politics, economics or social well-being in general, are religious duties, in no way different from prayers, fasts and the organization of social charity'. I handed over the choice of my partner to divine intervention.

Spirituality has two benefits for individuals: opportunity to rediscover oneself, cope with difficult situations and take critical decisions without worrying about the consequences (Siegel \& Schrimshaw 2002). In my case, I believed that God would be in charge of my marriage. I had a belief in a greater force that is powerful beyond time and physical beings and spaces. My spirituality enabled me to rise above the many instances of discrimination I had experienced due to being a female child; I believed that God would give me a man who would protect and cherish me.

Spirituality rejuvenates your soul: After being disregarded and treated like a second-class citizen, I had learned to leave the control of my life to God. In a way, I taught myself to be content with whatever happened in my life; I believed strongly that God would not give me a burden I could not handle. Spirituality carried me throughout my childhood, and my experiences of boys being treated better than girls. Spirituality kept me positive when I was a maid to generate money to attend a tertiary institution. It was as a result of my beliefs that I received a scholarship and attended university in another country. Through spirituality, I excelled at university, because I was not pursuing an education for the sake of it, but so I could return home and promote the dignity and education of the girl child. So, once I completed my Bachelors' degree, I was fully revitalised and believed I would meet a strong, God-sent man to protect me and father my children.

Delayed or a lack of vigilant response to abuse: Chisale (2018), in a paper 
on 'Domestic Abuse in Marriage and Self-silencing: Pastoral Care in a Context of Silencing', states that religion complicates the fight against domestic violence. She quotes a verse from the Bible (Proverbs 21:9), which, she contends, 'is used to justify self-silencing'. Hassouneh-Phillips (2003) agrees with this notion in her research on Abused American Muslim women's lives; she states that spirituality makes women more susceptible to domestic violence, and they find it difficult to stand up to. Most abused women keep their marital abuse a secret, because they fear humiliation and spiteful attacks for washing their dirty linen in public. In Islam, whoever conceals [the faults of] a Muslim, Allah will conceal [his faults] in this life and the Hereafter (Muslim). So, it is because of their spirituality that most abused women do not respond to, or delay responding to abuse. I also believed that keeping quiet about my marital challenges meant that I was a good believer. However, an analysis of publications, like that of Chisale, illustrates the extent to which spirituality can lead people to tolerate oppression, and thinking they are doing well.

\section{Plights of a Muslim Wife and Misinterpretation of the Religious Script}

My primary aim is to present my lived experience of being a Muslim wife. In doing so, I ask myself the question: Did my spirituality protect me or make me more vulnerable? In the next section I present and discuss themes in light of the religious scripts that motivated my behaviour. I go further, to show how my misinterpretation of the religious script could have led to my vulnerability. In every religious context, there are popular verses and texts that tend to be overused to emphasise certain aspects of human interaction. These excerpts are usually a selection of verses deliberately selected by male scholars to subvert vulnerable groups, such as women.

\section{Importance of Respecting and Honouring a Mother}

In most cultures and societies, mothers are held in high esteem as the givers and nurturers of life, due to their sacred role of giving birth and looking after children. In many verses of the Holy Qur'an, Allah repeatedly emphasises the importance of excellent treatment of one's parents. Regarding our blessed mothers, God says in the Qur'an, 'And We have enjoined upon man kindness 
to his parent. His mother carried him with hardship and gave birth to him with hardship'. Prophet Muhammad (peace upon him) also emphasises the importance of a mother when he says, '[Your] Heaven lies under the feet of your mother' (Sahih Bukhari).

However, my husband said in the first few days of our marriage, 'My dear, if I am asked to choose between you and my mother, do not fool yourself .... I will always choose my mother!' When he uttered these words I was alarmed; I wondered why someone would make such a statement without any provocation. Then I responded calmly by saying: 'My love, I would wonder what kind of person would first ask you to choose. A mother and a wife are two different departments, each fulfils different roles in your life'. Through the years, my husband visited his mother, and claimed that his mother needed him. I was never invited to accompany him - his reason was that he was saving money. As a Muslim who knows that 'Heaven is under the feet of a mother', I sacrificed my own right to his time and affection, so he could tend to our mother, my mother-in-law.

Though I agree and understand the importance of a mother, I know that this Hadith was and is still misinterpreted, which leads to the ancient tension between mothers-in-law and daughters-in-law. In fact, some wives are deprived of their marital rights, including conjugal rights, because their husbands must tend to their mothers. The husband's quest to attain entrance to heaven through a mother is pursued at the expense of the wife. Many husbands fail to maintain the balance and fulfil the Qur'anic verse that states: 'They are an apparel for you and you are an apparel for them' (Chapter 2:188).

It is hard to understand why a man would take a woman from her parents' home, and abandon her at his home. Why would a husband buy elaborate gifts for his mother and the extended family, and fail to clothe and feed his wife? This is a typical case of misinterpretation of the religious text, which leads to marital abuse. Many women, myself included, believe that they will receive God's blessing if they sacrifice their happiness for happiness of their spouses and other family members.

\section{The Curse of the Angels}

The Prophet Muhammad emphasises the importance of romance, which is expressed by brushing one's teeth regularly, joking and playing with one's spouse and performing foreplay before penetration. However, most husbands 
tend to ignore these essentials of romance, and it causes bitterness and lack of interest in intimacy in the wife. Lovemaking is understood differently by different people; some place it in a dark bedroom under a blanket, and others know that it starts long before that. Some men expect their wives to do all the household chores, and to attend to the needs of children, visitors and some senior members of the family, without helping. Yet, when the wife gets to bed, exhausted, she is expected to automatically turn her tired body 'on' and provide sexual pleasure. Societal narratives point out that, regardless of the wife saying that she is exhausted and would like to sleep, the husband still demands his right to intimacy. If the wife does not acquiesce, she is likely to be told that the angels will curse her the whole night. 'It is obligatory for the wife to obey her husband if he calls her to his bed. If she refuses, she is sinning' (Al-Ikhtiyaaraat alFiqhiyyah p. 246).

This scripture has been misinterpreted and misused, to prevent women from advocating for their husbands to be involved in the running of the household, or paying for a helper to assist with household chores. A wife who is not exhausted by housework would, perhaps, have time to beautify herself, to be playful and to enjoy her husband's romantic attention. Some men complain that their wives stop grooming themselves to remain attractive after marriage, but the men don't realise that the wife has no time for that when she is swamped by children and never-ending chores. In African Muslim marriages, wives are expected to wash, cook and serve the whole family; such expectations are perpetuated by popular wedding songs, such as Umakoti ungowethu [the bride is ours] uzosiwashela asiphekele [she is going to wash and cook for us] Siyavuma [we agree]. The participants in the study by AlGhafli et al. (2014) reported misconceptions regarding gender roles, which lead to men believing they have no role to play in keeping their homes tidy and habitable. The Prophet Muhammad did housework, he cooked, mended his clothes, etc. as well as many other things. Muslims claim to emulate the Prophet, but they are selective in their practice when they supposedly emulate him. They also tend to misrepresent Islam to favour themselves.

In the process of my misguided spirituality and cultural conditioning, I thought that going to work, and then, upon my return, exhausting myself with housework, would make me the best Muslim wife. Considering the rights of a Muslim wife, I realise that I should have encouraged my husband to pay for a helper to assist with household chores, so I could spend quality time with him and our children. 


\section{God Loves those who Persevere}

Islam, like most religions, refers to the importance of exercising patience. However, the need to be patient is overemphasised for women, and portrayed as the most important ingredient for a successful marriage. The following verses are often quoted to indicate that godliness lies in perseverance: 'Indeed, Allah is with those who patiently endure' (Qur'an 8: 46); 'Indeed, the patient will be given their reward without account' (Qur'an 39:10).

Chisale (2016) posits that ukubekezela (exercising patience) is a biased practice that focuses on making women responsible for carrying the burden of marriage. She argues that societies should teach men to be patient and exert effort to make their marriages and relationships work. In my marriage, I, too, applied these verses in a misguided manner. I thought that, regardless of how unhappy I was, I had to be patient because God was happy with me. In the process of persevering, women could indirectly reinforce their husbands' belief that the wives are content with the status quo. God is loving and merciful and, therefore, dislikes injustice and maltreatment. It is critical to avoid informing spirituality by dominating (re)interpretations of religious scripts.

\section{Searching to Liberate Muslim Wives}

The question I seek to answer in this paper is, did my spirituality protect me or make me more vulnerable? As I argued above, I was made vulnerable by my misinterpretations of religious scripts and my spirituality in relation to it. Although I was aware that both my partner and I interpreted the Qur'an naïvely, I kept my silence, because I, like many other women, had been socialised to be silent. Nevertheless, I resisted and contested this misinterpretation in my private space. Chisale (2017) argues that women resist patriarchy and the oppression of marriage in diverse ways. In the Islamic belief, women cope with abuse through spirituality, Qur'anic recitation, prayer (salaah) and meditation (dhikr) (Hassouneh-Phillips 2003).

African women who are theology scholars continue to contest the misinterpretation of religious scripts and call on women and men to unite and interpret religious scripts in life-affirming ways (Kanyoro 2001; Oduyoye 2001). The challenge is not the scripture, but the way the scripture is interpreted. It is, therefore, imperative that, in spite of limited involvement of women in the leadership roles of religious affairs, platforms should be created for women to create harmonious families and communities. 
I believe that more Muslim women should learn the Arabic language, so they can have a better understanding of various liberating scripts in the Holy Book. There should be more platforms where the religious scripts are discussed, with the aim of promoting respect for all humans, including women. Since it is already known which texts tend to be misinterpreted, and which lead to the oppression of women, these texts should be targeted specifically and debunked, to empower both men and women, and strengthen marriages. Since I learnt the appropriate interpretations of the scripture, I now stand my ground and oppose any kind of oppression. I oppose anyone who makes me feel as if I am a slave who does not deserve to be treated with love and kindness. Hassouneh-Phillips (2001a) points out that most oppressed Muslim women end up leaving their partners, because their husbands refuse to change their behaviour. She does, however, also mention that religion and spirituality cause women to put off leaving their abusive marriages. Cohen and Savaya (1997) assert that, because Islam frowns on divorce, abuse victims put off leaving, before they eventually abandon their marriages. My personal experience is a case in point; my spirituality gave me the strength to persevere in an unhappy situation. The fact that Islamic scholars emphasise God's disapproval of divorce, instead of emphasising God's love for justice, makes many women stay in abusive marriages.

\section{Conclusion}

This paper focused on whether my spirituality made me more vulnerable. It is clear that the misinterpretation of religious scripts led to my oppression. The author acknowledges that her experience could have been influenced by her own misguided spirituality and cultural conditioning. She goes to great lengths to illustrate how misunderstanding of the most liberating aspects of Islam could lead to subjugation of one group by another. She argues that being socialised in misogynistic ways leads to deliberate exclusion of women and consideration of women as inferior purely because they are women. The study illustrates that Islamic pedagogies and ideologies actually promote women's rights. As a result, this paper argues that women should learn and understand religious scripts on a personal level, to enjoy the maximum liberation these scripts provide. These rights can be enjoyed if both men and women manage their power relations and implement religious teachings appropriately. The rate of abuse of women is likely to decrease if people can desist from using religion 
and culture to perpetuate discriminatory behaviour. There is a need for spirituality to be applied in a way that will make women feel safe.

\section{References}

Chisale, S.S. 2016. 'For better or worse': Pedagogies of Premarital Counselling and Intimate Wife Abuse: An African Woman's Interpretation. Journal of Gender and Religion in Africa 22,1: 55 - 69.

Chisale, S.S. 2017. Patriarchy and Resistance: A Feminist Symbolic Interactionist Perspective of Highly Educated Married Black Women. Unpublished Masters dissertation. University of South Africa.

Chisale, S.S. 2018. Domestic Abuse in Marriage and Self-silencing: Pastoral Care in a Context of Self-silencing. HTS Teologiese Studies/ Theological Studies 74,2: 4784. https://doi.org/10.4102/hts.v74i2.4784

Cohen, O. \& R. Savaya 1997. 'Broken Glass': The Divorced Woman in Moslem Arab Society in Israel. Family Process 36,3: 225 - 245.

https://doi.org/10.1111/j.1545-5300.1997.00225.x

PMid:9439936

Geisinger, B.N. 2011. Critical Feminist Theory, Rape, and Hooking up.

Master's thesis. Iowa State University. Available at:

https://lib.dr.iastate.edu/etd/12123

Ghorbani, N., P.J. Watson, S. Geranmayepour \& Z. Chen 2013. Analyzing the Spirituality of Muslim Experiential Religiousness: Relationships with Psychological Measures of Islamic Religiousness in Iran. Archive for the Psychology of Religion 35,2: 233 - 258. Available at:

http://dx.doi.org/10.1163/15736121-12341264

Ghorbani, N., P.J. Watson, S. Geranmayepour \& Z. Chen 2014. Measuring Muslim Spirituality: Relationships of Muslim Experiential Religiousness with Religious and Psychological Adjustment in Iran. Journal of Muslim Mental Health 8,1: 77 - 94.

https://doi.org/10.3998/jmmh.10381607.0008.105

Hassouneh-Phillips, D.S. 2001a. American Muslim Women's Experiences of

Leaving Abusive Relationships. Health Care for Women International 22,4: 415 - 432.

https://doi.org/10.1080/07399330119163

PMid:11813788 
Hassouneh-Phillips, D.S. 2001b. Marriage is Half of Faith and the Rest is Fear Allah: Marriage and Spousal Abuse among American Muslims. Violence Against Women 7,8: 927 - 946.

https://doi.org/10.1177/10778010122182839

Hassouneh-Phillips, D. 2003. Strength and Vulnerability: Spirituality in Abused American Muslim Women's lives. Issues in Mental Health Nursing 24,6-7: 681 - 694.

https://doi.org/10.1080/01612840305324

PMid:12907383

Kanyoro, M.R.A. 2001. Engendered Communal Theology: African Women's

Contribution to Theology in the $21^{\text {st }}$ Century. In Njoroge, N.J. \& M.W.

Dube (eds): Talitha cum! Theologies of African Women. Pietermaritzburg:

Cluster Publications. https://doi.org/10.1177/096673500100002704

Khalil, Amal Ibrahim Abd El-Fattah 2016. The Islamic Perspective of Inter-

personal Communication. Journal of Islamic Studies 4, 2: 22 - 37.

https://doi.org/10.15640/jisc.v4n2a3

Oduyoye, M.A. 2001. Introducing African Women's Theology. Ohio: The

Pilgrim Press, Peter Lang.

Macdonald, M. 2006. Muslim Women and the Veil: Problems of Image and

Voice in Media Representations. Feminist Media Studies 6: 7 - 23.

https://doi.org/10.1080/14680770500471004

MacKinnon, C. 1983. Feminism, Marxism, Method and the State: Toward Feminist Jurisprudence. Signs 7: 515 - 544.

https://doi.org/10.1086/493898

MacKinnon, C. 1991. Reflections on Sex Equality under the Law. The Yale Law Journal 100,5: 1281 - 1328.

https://doi.org/10.2307/796693

Mangena, F. 2008. Natural Law Ethics, Hunhuism and the Concept of Retributive Justice among the Korekore-Nyombwe People of Northern Zimbabwe: An Ethical Investigation. D.Phil. thesis. Harare: University of Zimbabwe.

Mbiti, J. 1970. African Religions and Philosophies. New York: Anchor.

Pargament, K.I. 2013. Searching for the Sacred: Toward a Non-reductionistic Theory of Spirituality. In Pargament, K.I., J.J. Exline \& J.W. Jones (eds.): APA Handbook of Psychology, Religion, and Spirituality. Volume 1:

Context, Theory, and Research. Washington, DC: American Psychological Association. https://doi.org/10.1037/14045-000 
Ramose, M. 1998. The Philosophy of Ubuntu and Ubuntu as a Philosophy. In Coetzee, P.H. \& A.P. Roux (eds): Philosophy from Africa. Cape Town: Oxford University Press.

Șahịh al-Bukhārī 5665.

Scatlas, W.P. 1992. Do Feminist Ethics Encounter Feminist Aims? Indiana: Indiana University Press.

Siddiqi, M.M. 1984. Women in Islam. Delhi: Prominent Printers.

Siegel, K. \& E. Schrimshaw 2002. The Perceived Benefits of Religious and Spiritual Coping among Older Adults Living with HIV/ AIDS. Journal for the Scientific Study of Religion 41,1: 81 - 102.

https://doi.org/10.1111/1468-5906.00103

Wall, S. 2006. An Autoethnography on Learning about Autoethnography. International Journal of Qualitative Methods 5,2. Available at: http://www.ualberta.ca/ iiqm/backissues/5_2/pdf/wall.pdf https://doi.org/10.1177/160940690600500205

Weiler, K. 1988. Women Teaching for Change: Gender, Class and Power. New York: Bergin \& Garvey.

Sindile A. Ngubane-Mokiwa (PhD) Associate Professor and Head of Department Institute for Open Distance Learning College of Graduate Studies University of South Africa mokiwsa@unisa.ac.za 